\title{
Edaphic-Climatic Zoning of Eucalyptus Species in the Rio de Janeiro State, Brazil
}

\author{
Tamires Partélli Correia ${ }^{1}$ (D), Dayanne de Oliveira Prado ${ }^{2}$ (D), \\ Gustavo Bastos Lyra² (D), Emanuel José Gomes de Araújo³ (D), \\ Guilherme Bastos Lyra ${ }^{4}$
}

\footnotetext{
${ }^{1}$ Programa de Pós-graduação em Ciências Ambientais e Florestais, Instituto de Florestas, Universidade Federal Rural do Rio de Janeiro - UFRRJ, Seropédica/RJ, Brasil

${ }^{2}$ Departamento de Ciências Ambientais, Instituto de Florestas, Universidade Federal Rural do Rio de Janeiro - UFRRJ, Seropédica/RJ, Brasil

${ }^{3}$ Departamento de Silvicultura, Instituto de Florestas, Universidade Federal Rural do Rio de Janeiro - UFRRJ, Seropédica/RJ, Brasil

${ }^{4}$ Centro de Ciências Agrárias, Laboratorio de Irrigação e Agrometeorologia, Universidade Federal de Alagoas - UFAL, Rio Largo, Brasil
}

\begin{abstract}
The aim of this study was to perform the edaphic-climatic zoning of six eucalyptus species (E. camaldulensis, C. citriodora, E. cloeziana, E. grandis, E. saligna, and E. urophylla) in the state of Rio de Janeiro (RJ). The edaphic-climatic zoning was determined by overlayer of thermal and water (water deficit [DEF] and rainfall), type of soils (pedology), and relief (altitude) suitability maps. Suitability maps were obtained using Geographic Resources Analysis Support System (GRASS-GIS). The species studied showed potential for cultivation in the entire RJ due to different tolerances and requirements to the environmental conditions. The exception was the E. saligna, which proved to be unsuitable for the entire state, while C. citriodora showed the greatest suitability. Among edaphic-climatic factors analyzed, air temperature and DEF were the most important limiting factor for the suitability of species.
\end{abstract}

Keywords: forestry production, suitability maps, Geographic Information System (GIS). 


\section{INTRODUCTION}

In Brazil, the forest sector is responsible for approximately $5.5 \%$ of the Gross Domestic Product - GDP. In 2014, the GDP of the Brazilian sector of planted trees increased by $1.7 \%$. In the same year, the sector accounted for about $\mathrm{R} \$ 10.23$ billion in federal, state, and local taxes, which accounted for $0.8 \%$ of the national revenue. The planted forest sector also accounted for generating 4.23 million direct and indirect jobs and those resulting from the income effect (IBÁ, 2015). However, the potential of the forest sector in the country is still underused in some regions. In the state of Rio de Janeiro (RJ), for example, the reforested area is only 18,427 ha, which corresponds to $0.42 \%$ of the total area of the state and less than $0.1 \%$ of the area covered with planted forests in the country (Paula et al., 2012). Timber production in this area does not meet the domestic demand of RJ, which makes it a large importer of wood for different purposes of the economic sector (Amorim et al., 2012).

Eucalyptus started being intensively cultivated in Brazil in the 1950s, particularly by government tax incentives, to meet the demand for wood required at the beginning of the country's industrialization process. Since it was established, eucalyptus became a reference in studies and in genetic improvement programs due to its fast growth, tolerance, and multiple uses of wood (Tolfo et al., 2005). The species of the genus are used for production of railway sleepers, plates, panels, coal, pulp, paper, energy, extraction of essential oils, fence posts, poles, civil construction, and, recently, in the fine furniture industry (Wilcken et al., 2008).

Among the tree species planted in Brazil and in RJ, species of the genus Eucalyptus sp. stand out (IBÁ, 2015). Brazil has 7.74 million ha planted with eucalyptus, pine, and other species, but $71.9 \%$ of planted forests correspond to eucalyptus plantations. In 2014, the area cultivated with eucalyptus totaled 5.56 million hectares. The largest eucalyptus producers are the states of Minas Gerais (MG) (25.2\%), São Paulo (SP) (17.6\%), and Mato Grosso do Sul (MS) (14.5\%) (IBÁ, 2015). In RJ, eucalyptus plantations comprise $97.9 \%$ of reforested areas, with 18,039 ha (Amorim et al. 2012).

Species Eucalyptus camaldulensis Dehnh, Corymbia citriodora Hook, Eucalyptus cloeziana F. Muell, Eucalyptus grandis Hill ex Maiden, Eucalyptus saligna Smith, and
Eucalyptus urophila S.T. Blake are the most widely grown in RJ (Amorim et al., 2012). These species have different climate and soil requirements that represent most types of climates and soils in RJ. Species E. camaldulensis, C. citriodora, E. urophylla, and Eucalyptus cloeziana are commonly used in reforestation programs aimed at coal production.

C. citriodora is the main raw material used for essential oil extraction in Brazil, which is one of the largest producers of essential oils in the world. Timber from C. citriodora can be used mainly in the production of posts, fence posts, and wood (Vitti \& Brito, 1999). C. citriodora is the most cultivated species in SP and MG for essential oil extraction, energy, and civil construction (Silva et al., 2009). Timber from C. citriodora is rot-resistant, has good planing, sanding, drilling, and finishing features, and may be suitable for plantations targeting multiple uses, such as buildings, structures, boxes, poles, railway sleepers, fence posts, firewood, and coal (Calil-Júnior \& Dias, 1997). Its leaves are also used in perfume, pharmaceutical, chemical, and therapeutic industries and others (Vitti \& Brito, 1999).

E. saligna, when obtained from non-managed plantations, is recommended for general use, preferably for energy purposes. However, when properly handled, this species is used for fiber-based structures and panels. Regarding species E. cloeziana, the characteristic shape of shaft stands out, which ensures the production of logs with high use in the mechanical processing, and due to its high density and natural durability, it is widely used in rural and urban areas to meet needs of civil construction, production of stanchions, rafters, posts, and charcoal (Gonçalez et al., 2006). E. grandis is the most cultivated species in Brazil, has physical and mechanical properties of wood considered optimal for use in civil construction, great versatility, beauty and natural color, with good acceptance also in the furniture industry. The wood has light density, is easy to work, has light reddish brown color, fine texture and right grain (Lima \& Garcia, 2011). Thus, E. grandis may be recommended to replace native forest species. Currently, it also stands out as the main source of raw material for pulp and paper.

Forest crops are directly dependent on environmental factors, such as rainfall, air and soil temperature, humidity, solar radiation and wind (Pereira et al., 2002), relief features, and types of soils (Mafra et al., 2008). 
These factors, associated with the type of forest site, influence growth in diameter, height, and volume of trees, interfering with the definition of the species to be grown in a given region. For the survival phase of the seedling in the field, as well as for growth and yield, stress due to lack or excess of water is a limiting factor for plant growth and yield (Souza et al., 2006). Forest species managed in appropriate environmental conditions result in excellent growth (Lima \& Garcia, 2011). Thus, knowledge of the soil conditions, relief, and bioclimatic needs (climate conditions necessary for the occurrence of the living organism in a given place) of species support the decision-making in the forest area, and allow greater physical and economic success development of forest crops, regardless of their purpose.

The expansion of areas with planted forests, particularly in regions with large urban centers, such as SP and RJ, should be made in order to allow better use of physical space and minimize environmental impacts (Francelino et al., 2012). In this context, edaphic-climatic zoning consists in evaluating the main climatic and soil factors that influence the establishment, growth, and maximum crop yield. Thus, zoning aims at obtaining a diagnosis on the suitability of a given environment for potential cultivation of the species and support its management.

The aim of this study was to develop the edaphic-climatic zoning of six eucalyptus species (E. camaldulensis, C. citriodora, E. cloeziiniana, E. grandis, E. saligna, and E. urophila) in RJ.

\section{MATERIALS AND METHODS}

The study area included RJ, located in the eastern portion of southeastern Brazil, between latitudes $20^{\circ} 45^{\prime} 54^{\prime \prime}$ and $23^{\circ} 21^{\prime} 57^{\prime \prime}$ S and longitudes $40^{\circ} 57^{\prime} 59^{\prime \prime}$ and $44^{\circ} 53^{\prime} 18^{\prime \prime}$ $\mathrm{W}$. The state is divided into eight administrative regions (Northern, Metropolitan, Northeastern, Lowlands, Mountainous, Mid-southern, Middle Paraíba, and Green Coast). The state boundaries are at north with the state of Espírito Santo (ES), southeast with the Atlantic Ocean, north and northwest with MG, and southwest with SP (Figure 1).

The edaphic-climatic zoning was carried out for six eucalyptus species (E. camaldulensis, C. citriodora, E. cloeziana, E. grandis, E. saligna, and E. urophylla) described in the reforestation manual of RJ (Golfari, 1980). The species have distinct climatic and soil requirements, which include a variety of climates and

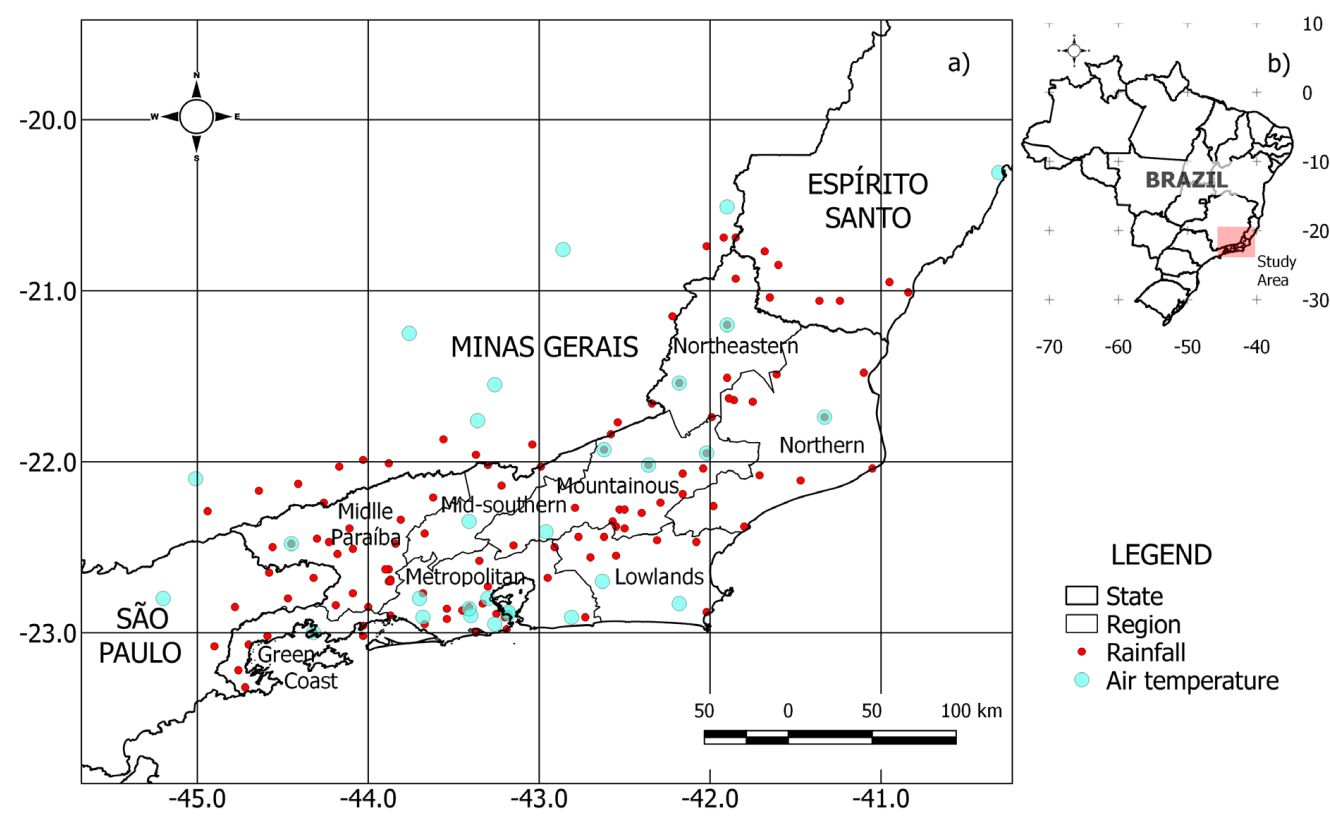

Figure 1. Geopolitical division of regions of the state of Rio de Janeiro (a), Brazil (b), and distribution of rainfall and/or weather stations (rainfall and/or air temperature) considered in zoning. 
topography and soil characteristics, and may have potential for reforestation in RJ. The soil, climate, and altitude requirements of species are presented in Table 1.

Annual and monthly climate series of rainfall and air temperature of weather and/or precipitation stations located in RJ and regions bordering SP, MG, and ES were used in the analysis of climate suitability of eucalyptus species. Monthly and annual series were determined from the daily series of these climatic elements obtained from the database of the Brazilian National Water Agency (Agência Nacional de Águas - ANA) with the aid of the HIDROWEB system (http://hidroweb.ana.gov. br), in the Brazilian National Institute of Meteorology (Instituto Nacional de Meteorologia - INMET) and/or Meteorological Network of the Brazilian Aeronautical Command (Rede de Meteorologia do Comando da Aeronaútica - REDEMET). Only stations with series higher than or equal to 20 years for rainfall and 15 years for air temperature were selected. In both cases, series between 1960-2010 period.

From the daily series, the accumulated monthly and annual rainfall was determined and, regarding air temperature, the monthly and annual averages were obtained. The monthly series of climatic elements were submitted to the data quality control based on recommendations of the World Meteorological Organization (WMO). In the case of accumulated monthly and annual rainfall, after quality control, the filling of gaps of monthly data was performed. In the filling of gaps, linear regression method was used (Lyra et al., 2017).

A multiple linear regression model (Equation 1) was fitted to monthly and annual series of air temperature (dependent variable) as a function of latitude, longitude, and altitude (independent variables) (Lyra et al., 2011):

$\mathrm{T}_{\mathrm{ar}, \mathrm{i}}=\beta_{0}+\beta_{1} \phi_{\mathrm{i}}+\beta_{2} \lambda_{\mathrm{i}}+\beta_{3} \mathrm{Z}_{\mathrm{i}}+\varepsilon_{\mathrm{i}}$

where $T_{a r}\left({ }^{\circ} \mathrm{C}\right)$ is the monthly or annual air temperature (dependent variable) and the independent variables $\phi$ is the latitude (degrees), $\lambda$ is the longitude (degrees), $Z$ $(\mathrm{m})$ is the altitude, and $\varepsilon_{\mathrm{i}}$ is the random error assumed as independent and with normal distribution of the average and constant variance. The term i denote the i-th weather station.

Table 1. Edaphic-climatic requirements of eucalyptus species selected for zoning based on altitude (m), air temperature $\left(\mathrm{T}_{\mathrm{ar}}\right)$, rainfall, water deficit $(\mathrm{DEF})$ and type of soil.

\begin{tabular}{|c|c|c|c|c|c|}
\hline Species & $\begin{array}{l}\text { Altitude } \\
(\mathrm{m})\end{array}$ & $\begin{array}{c}\mathrm{T}_{\mathrm{ar}} \\
\left({ }^{\circ} \mathrm{C}\right)\end{array}$ & $\begin{array}{l}\text { Rainfall } \\
\text { (mm) }\end{array}$ & $\begin{array}{c}\text { DEF } \\
(\mathrm{mm})\end{array}$ & Soil \\
\hline E. camaldulensis & $0-300$ & $20-24$ & $800-1,200$ & $10-300$ & $\begin{array}{l}\text { Latosols, Histosols, Gleysols, Acrisols, } \\
\text { Regosols, Tertiary, and Alluvial Latosols }\end{array}$ \\
\hline C. citriodora & $0-800$ & $18-24$ & $800-1,600$ & $10-300$ & $\begin{array}{l}\text { Latosols, Histosols, Gleysolos, Acrisols, } \\
\text { Regosols, Latosols and Acrisols associated } \\
\text { (soils with argillic horizon and high base } \\
\text { saturation), tertiary, and alluvial Latosols }\end{array}$ \\
\hline E. cloeziana & $0-800$ & $18-24$ & $1,000-2,600$ & $0-60$ & $\begin{array}{l}\text { Latosols, Histosols, Gleysols, Acrisols And } \\
\text { Regosols associated, Latosols and Acrisols } \\
\text { associated (soils with argillic horizon and } \\
\text { high base saturation), Fluvisol, Leptosols } \\
\text { and Latosols associated, Gleysols, and } \\
\text { Acrisols associated }\end{array}$ \\
\hline E. saligna & $0-800$ & $13-18$ & $1,500-2,400$ & $0-10$ & $\begin{array}{l}\text { Leptosols e Latosols associated, Regosols } \\
\text { and Latosols associated }\end{array}$ \\
\hline E. urophylla & $0-800$ & $18-24$ & $1,000-2,600$ & $0-100$ & $\begin{array}{l}\text { Latosols, Histosols, Gleysols, Acrisols, } \\
\text { Regosols, Latosols and Acrisols associ- } \\
\text { ated, (soils with argillic horizon and high } \\
\text { base saturation), Fluvisols, Leptosols and } \\
\text { Latosols associated, Acrisols, and tertiary } \\
\text { Latosols }\end{array}$ \\
\hline E. grandis & $0-2,000$ & $13-24$ & $1,000-2,600$ & $0-60$ & $\begin{array}{l}\text { Latosols, Histosols, Gleysols, Acrisols and } \\
\text { Regosols associated, Latosols and Acrisols } \\
\text { associated (soils with argillic horizon and } \\
\text { high base saturation), Fluvisols, Leptosols } \\
\text { and Latosols associated }\end{array}$ \\
\hline
\end{tabular}

Source: Adapted from Golfari (1980). 
From the fitted coefficients, the regression model (Equation 1) was used to estimate the monthly air temperature in geographic coordinates (latitude and longitude) and altitude of weather or precipitation stations with rainfall series only. The monthly air temperature and rainfall were used to calculate the water balance $(\mathrm{WB})$ and the water deficit (DEF) for eucalyptus in every station. The method used to calculate WB was the method of Thornthwaite \& Mather (1955) implemented in Excel spreadsheet by Rolim et al. (1998). The available water capacity value $(\mathrm{AWC}=\mathrm{AW} \times \mathrm{Z})$ in the soil was estimated for soil characteristics where each station was located. For this, the soil available water map (AW, $\mathrm{mm} / \mathrm{m})$ was considered, which was prepared by the Food and Agriculture Organization (FAO, 2007), and an effective depth of the root system $(\mathrm{Z}, \mathrm{m})$ for forest species of $1.5 \mathrm{~m}$ (Pereira et al., 2002).

Spatial interpolation of annual rainfall and DEF was performed, which was obtained by the WB for the eucalyptus species for RJ by the regularized spline tension method using the software Geographic Resources Analysis Support System (GRASS-GIS) (Lyra et al., 2017). In the interpolation, the region between latitudes $20^{\circ} 45^{\prime} 54^{\prime \prime}$ and $23^{\circ} 21^{\prime} 57^{\prime \prime} S$ and longitudes 40 $57^{\prime} 59^{\prime \prime}$ and $44^{\circ} 53^{\prime} 18^{\prime \prime} \mathrm{W}$ was considered, with spatial resolution of $90 \mathrm{~m}$.

The spatial interpolation of the annual air temperature using multiple linear regression, the coefficients previously fitted, was resolved in a regular grid with geographical coordinates and based on the altitude map (Lyra et al., 2011). The altitude was represented by the Digital Elevation Model (DEM) in the raster format developed by the Shuttle Radar Topography Mission - SRTM (USGS, 2013) project. For the numerical resolution of the air temperature regression in the same area and resolution considered in the rainfall and DEF interpolation, the map calculator module (r.mapcalc) of the GRASS-GIS and the DEM SRTM were used.

For altitude variable, the classification of eucalyptus species was based on DEM SRTM with spatial resolution of $90 \mathrm{~m}$. The DEM SRTM used in this study was treated by Empresa Brasileira de Pesquisa Agropecuária Embrapa researchers to eliminate flaws, shadows, and distortions (Brubacher et al., 2012).

Soil analyses were based on pedological survey available with the third edition of the Brazilian System of Soil Classification (Sistema Brasileiro de Classificação de Solos - SiBCS), coordinated by Embrapa (EMBRAPA, 2013). In addition to classes reactive to type of soil, the map had some classes of soil use and occupation (e.g., urban area, water body, and rocky outcrops). The map in vector format has been transformed into raster format with resolution of $90 \mathrm{~m}$ for the analyses, maintaining the original classes of vector soil polygons.

To obtain the water fitness of eucalyptus species assessed, the annual precipitation and DEF maps were imported into SIG GRASS, being reclassified (reclass module) into suitable (1) or unsuitable (0), based on the water needs of species proposed by Golfari (1980) and shown in Table 1. The air temperature map has also been reclassified into suitable (1) or unsuitable (0), according to the thermal requirements of each species to obtain the thermal fitness map.

To generate the relief and soil suitability maps, the maps with elevation and soil classes were reclassified based on the classes shown in Table 1 to determine areas suitable (1) or unsuitable (0) for the cultivation of eucalyptus species evaluated. In the soil suitability, soil use and occupation was also considered, so the areas described as water bodies, rocky outcrops, and urban areas have been reclassified with value 0 , that is, unsuitable for all species. The calculation of suitable and unsuitable areas in $\mathrm{km}^{2}$ and percentage was determined considering the eight administration regions of RJ.

The final edaphic-climatic zoning was obtained by multiplying the water (rainfall and DEF), thermal, relief, and soil suitability maps. The multiplication of maps was carried out in the SIG GRASS environment through its r.mapcalc module. Since suitable classes received value 1 and unsuitable 0 for the final map, with the multiplication product, the pixel with value 1 was considered suitable and 0 unsuitable for the cultivation of eucalyptus species evaluated. The final zoning maps have spatial resolution of $90 \mathrm{~m}$.

\section{RESULTS AND DISCUSSION}

Table 2 shows the absolute $\left(\mathrm{km}^{2}\right)$ and relative (\%) areas suitable and unsuitable for the cultivation of six species evaluated in the edaphic-climatic zoning for RJ. C. citriodora species showed the largest area suitable for cultivation in the state, corresponding to $48.73 \%$ of the total area of RJ; the second most suitable species was E. urophylla, with $36.37 \%$ of suitable area, then E. grandis 
Table 2. Areas identified as suitable and unsuitable for the cultivation of eucalyptus species and their percentage in relation to area of the state of Rio de Janeiro*, Brazil.

\begin{tabular}{lcccc}
\multicolumn{1}{c}{ Species } & $\begin{array}{c}\text { Unsuitable Area } \\
\left(\mathbf{k m}^{2}\right)\end{array}$ & $\begin{array}{c}\text { Unsuitable Area } \\
\mathbf{( \% )}\end{array}$ & $\begin{array}{c}\text { Suitable Area } \\
\left(\mathbf{k m}^{2}\right)\end{array}$ & $\begin{array}{c}\text { Suitable Area } \\
(\%)\end{array}$ \\
\hline E. camaldulensis & $38,821.19$ & 89.45 & $4,579.00$ & 10.55 \\
\hline C. citriodora & $22,867.29$ & 52.69 & $20,533.32$ & 47.31 \\
\hline E. grandis & $33,311.72$ & 76.75 & $10,088.89$ & 23.25 \\
\hline E. saligna & $43,400.61$ & 100 & - & - \\
\hline E. urophylla & $29,770.91$ & 68.60 & $13,629.7$ & 31.40 \\
\hline E. cloeziana & $34,009.08$ & 78.36 & $9,391.53$ & 21.64 \\
\hline
\end{tabular}

* Total area of the state of Rio de Janeiro: $42,400.61 \mathrm{~km}^{2}$.

(27.57\%) and E. cloeziana (25.68\%). E. camaldulensis had only $10.81 \%$ of the state area considered suitable for its cultivation. Of the six species, only E. saligna was unsuitable for cultivation in the state. This result is due to the species restrictions.

E. saligna presented thermal constraints for cultivation in most of the state, since the species requires air temperature below $18{ }^{\circ} \mathrm{C}$. In RJ, air temperatures less than $18^{\circ} \mathrm{C}$ are observed only in the southern Mountainous region (bordering SP) and at the Serra da Mantiqueira, triple border with SP and MG. It also has low tolerance to drought and is suitable only for DEF values below or equal to $10 \mathrm{~mm}$. Soil was the main factor that restricted the suitability of the species, since the species is not suitable for soil class of higher occurrence in the state, the argisols. In addition, it showed the greatest rainfall constraint among species evaluated, since its water requirement is of at least $1,500 \mathrm{~mm}$ year ${ }^{-1}$.

In order to evaluate the effects of climatic conditions on biomass and nutrient content of E. grandis and E. saligna, Santana et al. (1999) chose five forest sites located in SP. The sites have different soil and climatic characteristics and were chosen to evaluate the effect of climatic conditions to determine the best forest site. As a result, the authors concluded that the effect of the site was more important for biomass production than the effect of the genetic material. E. saligna had better development in the municipality with milder air temperature conditions, such as São Miguel Arcanjo, which has average annual isotherms of $18^{\circ} \mathrm{C}$, has no DEF, and average rainfall of $1,400 \mathrm{~mm}$.

E. urophylla exhibits good tolerance to DEF (up to $100 \mathrm{~mm}$ ), also tolerates high levels of annual rainfall (up to 2,600 $\mathrm{mm}$ ) and regions with moderate elevations (up to $800 \mathrm{~m}$ ). Rainfall for E. urophylla was the smallest restriction and air temperature was the factor that limited its suitability in RJ. E. grandis, which was the third species with the highest suitable area to the state, has among species zoned in the study, the greatest suitability range, altitude $(0-2,000 \mathrm{~m})$, air temperature $\left(13-24^{\circ} \mathrm{C}\right)$, rainfall $(1,000-2,600 \mathrm{~mm})$, and soil classes (suitable for almost all types of soils), and the factor that restricts the cultivation of the species was DEF, with low tolerance $(0-60 \mathrm{~mm})$. Suitable areas are more concentrated in the inner state, where air temperature values less than $24^{\circ} \mathrm{C}$ and rainfall higher than 1,000 $\mathrm{mm}$ are observed. Areas with these characteristics also coincide with DEF of up to $60 \mathrm{~mm}$.

For E. cloeziana in the zoning of RJ, the air temperature was the most limiting factor, ranging from 18 to $24{ }^{\circ} \mathrm{C}$, which makes the whole coastal environment (coastal plains) unsuitable for cultivation. In areas of higher altitudes, consequently with lower air temperatures, the species had larger suitable areas. Regarding precipitation, the ideal range for the species is from 1,000 to $2,600 \mathrm{~mm}$. The species is tolerant to high rainfall amounts; however, it tolerates low DEFs $(60 \mathrm{~mm})$. For the type of soil, the species is also suitable for the most predominant soils in the state: leptosol, acrisol, and ferrasol.

For E. camaldulensis, the climatic elements that most restricted its suitability in the state were air temperature and rainfall. Every coastal environment was deemed unsuitable for presenting average air temperature values above the limit considered suitable for the cultivation of the species $\left(24^{\circ} \mathrm{C}\right)$. The Mountainous region restricts the cultivation of the species due to its low air temperatures, with annual average around $12^{\circ} \mathrm{C}$. Areas with annual total rainfall values lower than $800 \mathrm{~mm}$ or larger than $1,200 \mathrm{~mm}$ were characterized as unsuitable. In the Mountainous region, for example, 
the species is unsuitable due to annual rainfall values greater than $2,900 \mathrm{~mm}$. The cultivation of the species was characterized as unsuitable throughout the Mid-southern region, much of the Metropolitan region and the Mountainous region. In relation to type of soil, these regions have clayish soils, being suitable for this species. E. camaldulensis stands out in relation to other species of the genus due to its capacity to produce timber in poor and dry sites. It also has high tolerance to flooding, frost, extreme drought, and high temperatures periods, and respond with rapid growth when under adequate water availability (Schumacher \& Poggiani, 1993).

C. citriodora is suitable for regions with average altitude $(<800 \mathrm{~m})$, such as the northwestern region and part of the Northern region, and in smaller proportions in the Mountainous, Mid-southern, and Middle Paraíba regions. Due to restrictions on $\operatorname{DEF}(<300 \mathrm{~mm})$ and air temperature $\left(18-24^{\circ} \mathrm{C}\right)$, only narrow suitable areas were observed in Metropolitan regions and Lowlands. In the Green Coast region, the species was 100\% unsuitable, mainly due to high rainfall amounts (> 1,600 mm). The factors that restricted the suitability of the species were altitude and air temperature.

Table 3 shows the area of edaphic-climatic suitability for eight regions of RJ, while Figure 2 shows edaphic-climatic zoning maps for these regions. For E. camaldulensis, areas located in the Northern, northwestern, and lowland regions were considered suitable for cultivation (Figure 2a). These areas have low altitudes and the highest air temperatures of the state. In the Lowlands, suitable areas were also those with higher temperatures, high DEF and low altitudes, being characteristics of the coastal regions of $\mathrm{RJ}$, and average rainfall $(<1,200 \mathrm{~mm})$. In relation to type of soil, these regions have clayish soils, being also suitable for this species. The factors that most restricted the suitability of the species in the state were air temperature and rainfall. All coastal environment was characterized as unsuitable because of the annual air temperatures was above $24^{\circ} \mathrm{C}$, i.e., above the considered optimal for the species $\left(20-24^{\circ} \mathrm{C}\right)$. The Mountainous region has restricted the suitability of the species due to the low air temperatures with annual average of up to $15^{\circ} \mathrm{C}$. Areas with total annual rainfall lower than $800 \mathrm{~mm}$ or larger than 1,200 $\mathrm{mm}$ were considered unsuitable. In the Mountainous region, considered unsuitable, annual rainfall values greater than $2,900 \mathrm{~mm}$ were observed. The cultivation of the species was characterized as unsuitable throughout the Middle Paraíba and Green Coast regions, and virtually the entire Mid-southern region ( $0.5 \%$ of suitable area).

C. citriodora was the species with the largest suitable area for the Northern, Metropolitan, Northwestern regions, and Lowlands (Figure 2b). These regions suitable for C. citriodora showed similar total rainfall. The similarity of rainfall occurs because these regions are located near the coastal environment and have low

Table 3. Areas characterized as suitable for the cultivation of eucalyptus species and their percentage in relation to the area of the eight regions of the state of Rio de Janeiro.

\begin{tabular}{|c|c|c|c|c|c|c|c|c|}
\hline Region & \multirow{2}{*}{\multicolumn{2}{|c|}{$\begin{array}{l}\text { Northern } \\
\left(\mathrm{km}^{2}\right)(\%)\end{array}$}} & \multirow{2}{*}{\multicolumn{2}{|c|}{$\begin{array}{c}\text { Metropolitan } \\
\left(\mathrm{km}^{2}\right)(\%)\end{array}$}} & \multicolumn{2}{|c|}{ Northeastern } & \multicolumn{2}{|c|}{ Low Lands } \\
\hline Species & & & & & $(\mathbf{k m}$ & & $(\mathbf{k m}$ & \\
\hline E. camaldulensis & $1,772.82$ & 18.3 & $1,040.84$ & 19.9 & $1,535.78$ & 28.6 & 295.94 & 5.9 \\
\hline C. citriodora & $4,579.21$ & 47.2 & $1,954.48$ & 37.2 & $5,041.83$ & 94.7 & $1,192.70$ & 23.8 \\
\hline E. grandis & 571.76 & 5.9 & $1,427.09$ & 27.2 & 432.73 & 8.1 & $1,291.39$ & 25.7 \\
\hline E. saligna & 0.00 & 0.0 & 0.00 & 0.0 & 0.00 & 0.0 & 0.00 & 0.0 \\
\hline E. urophylla & $1,379.21$ & 14.2 & $1,805.31$ & 34.4 & 942.19 & 17.7 & $1,783.94$ & 35.6 \\
\hline E. cloeziana & 571.76 & 5.9 & $1,416.82$ & 27.0 & 408.73 & 7.7 & $1,287.44$ & 25.7 \\
\hline Region & \multicolumn{2}{|c|}{ Mountainous } & \multicolumn{2}{|c|}{ Mid-southern } & \multicolumn{2}{|c|}{ Middle Paraíba } & \multicolumn{2}{|c|}{ Green Coast } \\
\hline Species & \multicolumn{2}{|c|}{$\left(\mathrm{km}^{2}\right)(\%)$} & \multicolumn{2}{|c|}{$\left(\mathrm{km}^{2}\right)(\%)$} & \multicolumn{2}{|c|}{$\left(\mathrm{km}^{2}\right)(\%)$} & \multicolumn{2}{|c|}{$\left(\mathrm{km}^{2}\right)(\%)$} \\
\hline E. camaldulensis & 30.18 & 0.4 & 15.88 & 0.5 & 0.00 & 0.0 & 0.0 & 0.0 \\
\hline C. citriodora & $2,801.75$ & 40.5 & $2,222.94$ & 73.8 & 3.355 .68 & 54.7 & 434.24 & 21.4 \\
\hline E. grandis & $1,569.05$ & 22.7 & $1,257.23$ & 41.7 & 4.980 .39 & 81.2 & 0.00 & 0.0 \\
\hline E. saligna & 0.00 & 0.0 & 0.00 & 0.0 & 0.00 & 0.0 & 0.00 & 0.0 \\
\hline E. urophylla & $2,550.58$ & 36.9 & $1,887.83$ & 62.6 & 4.999 .63 & 81.5 & 434.24 & 21.4 \\
\hline E. cloeziana & $1,003.37$ & 14.5 & $1,169.35$ & 38.8 & 4.851 .31 & 79.1 & 434.24 & 21.4 \\
\hline
\end{tabular}



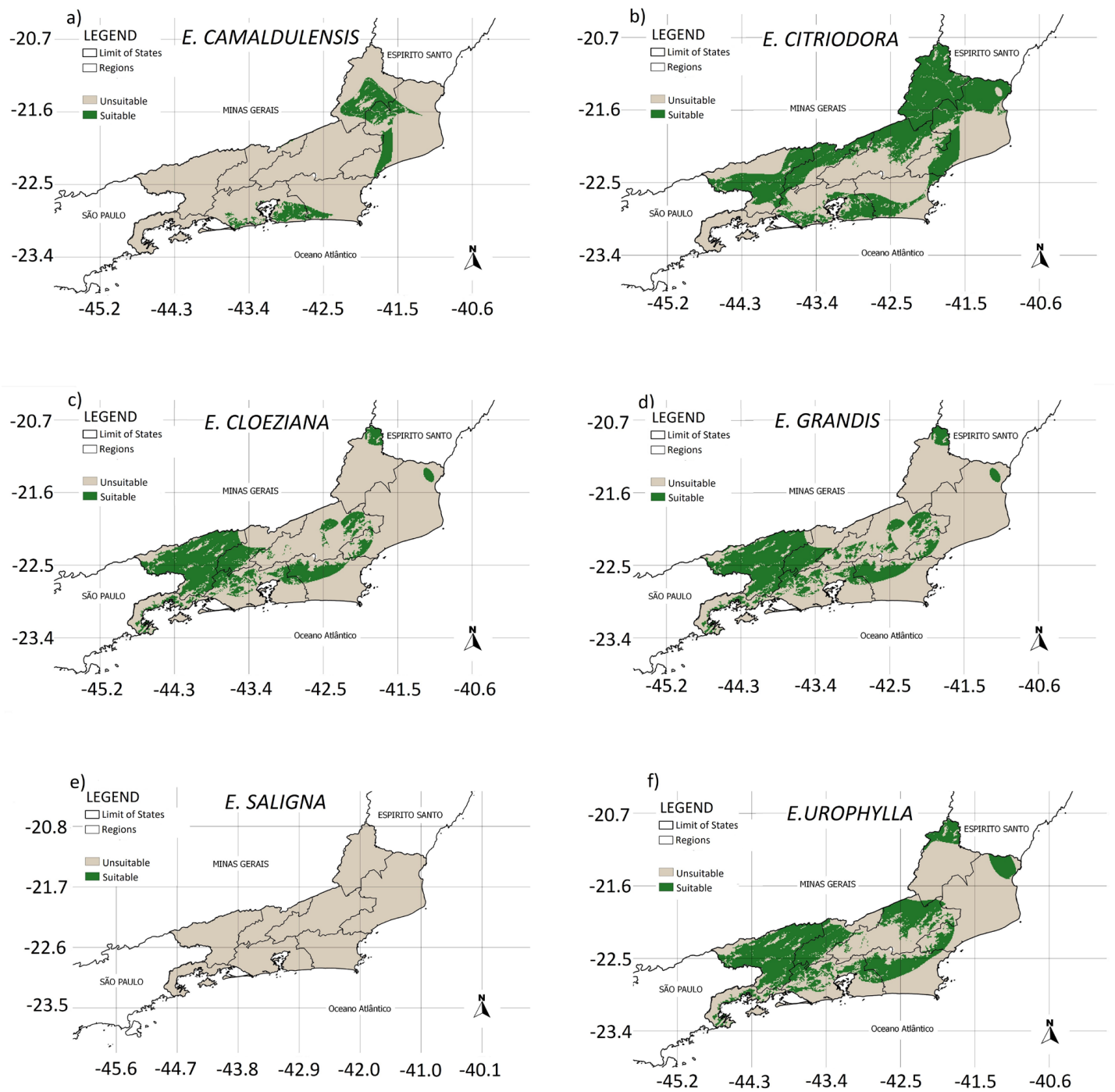

Figure 2. Edaphic-climatic zoning of eucalyptus species: a) E. camaldulensis, b) C. citriodora, c) E. cloeziana, d) E. grandis, e) E. saligna, and f) E. urophylla in the state of Rio de Janeiro, Brazil.

altitudes, which inhibits the orographic effect, and thus results in lower total rainfall. The exception is the Green Coast region, which is propitious for the occurrence of orographic rainfall, and thus contributes to higher total rainfall. Also with respect to rainfall, the optimal range of the species is suitable, which range from 800 to $1,600 \mathrm{~mm}$, being unsuitable only for extreme areas, such as the municipality of Cabo Frio, portions of the Northern region near the ocean or the areas with the largest total rainfall of the state, such as Green Coast, and most of the Mountainous region. Regarding altitude, only Serra do Mar and Serra dos Órgãos regions were considered unsuitable. For air temperature, areas considered suitable have similar climatic characteristics, with high annual average $\left(<24{ }^{\circ} \mathrm{C}\right)$, mainly in the Northern, Northwestern, and Metropolitan regions. The Mid-southern region has lower temperatures $\left(<22{ }^{\circ} \mathrm{C}\right)$ due to altitude. Regarding type of soil, the species was suitable for almost the entire state, being suitable for soils of predominance, such as oxisols and argisol.

For E. cloeziana, regions with the largest suitable areas were Metropolitan, Lowland, Mid-southern, and Middle Paraíba (Figure 2c). Mid-southern and Middle Paraíba regions resemble in annual air temperatures. The areas of Metropolitan and Lowland regions suitable 
for this species showed similar total average annual rainfall between 1,000 and 2,600 $\mathrm{mm}$.

E. grandis has suitability for Lowlands, Mountainous, Middle Paraíba and Green Coast (Figure 2d). This species can be grown at high altitudes and tolerates low temperatures. Its main restriction is the DEF $(<60 \mathrm{~mm})$, so, suitable areas also coincide with regions of high rainfall ( $>1,000 \mathrm{~mm}$ ), such as Mountainous and Green Coast.

For E. urophylla, regions with the largest suitable areas were Metropolitan, Mid-southern, Middle Paraíba, Green Coast, Mountainous and Lowland regions (Figure $2 \mathrm{f}$ ). It is the species with the most comprehensive suitability in the state. Only in the Northern and Northwestern regions suitable area was minimal, and the restriction to suitability in these areas was mainly due to the air temperature $\left(>24^{\circ} \mathrm{C}\right)$ and water stress (> $100 \mathrm{~mm}$ ).

The most relevant factor for the unsuitability of eucalyptus species in this study was the air temperature and DEF (WD). In the work by Sperandio (2010), the agro-ecological zoning for eucalyptus species in ES, the DEF, was also the most limiting factor for the suitability of the species. The species with the highest suitability (E. urophylla) had lower DEF and adaptation to withstand higher air temperature ranges.

\section{CONCLUSIONS}

E. citriodora was the species presenting the largest area with edaphic-climatic suitability in RJ, and the best conditions are presented in the following regions: Metropolitan, Northern, Northwestern, and Mid-Southern. E. saligna is unsuitable for the entire state. E. urophylla, E. cloeziana, and E. grandis are suitable for all regions of the state.

Of the eight regions, only Middle Paraíba and Green Coast were unsuitable for more than one species. The Metropolitan region has areas suitable for all species under study, with greater restriction for the presence of urban areas in almost every mesoregion.

From the edaphic-climatic zoning, it was possible to identify the main physical factors that provide suitability to crops and places of occurrence and to support planning and investment logistics in the forest area based on which location and species and the best use of their timber and non-timber derivatives, in addition to mapping optimum sites that will provide higher production yields.

\section{ACKNOWLEDGEMENTS}

To the Instituto Nacional de Meteorologia, Agência Nacional de Águas and Rede de Meteorologia do Comando da Aeronáutica for providing the climate series (air temperature and rainfall), to Empresa Brasileira de Brasileira de Pesquisa Agropecuária by the Pedological map, to Food Organization and Agriculture of the Nations United by the Water Available map and the Digital Elevation Model - SRTM available from the U.S. Geological Survey.

\section{SUBMISSION STATUS}

Received: 14 jul., 2016

Accepted: 24 jan., 2018

\section{CORRESPONDENCE TO}

\section{Gustavo Bastos Lyra}

Departamento de Ciências Ambientais, Instituto de Florestas, Universidade Federal Rural do Rio de Janeiro - UFRRJ, Rodovia BR 465, CEP: 23890-000, Seropédica, RJ, Brasil e-mail:gblyra@gmail.com; gblyra@ufrrj.br

\section{FINANCIAL SUPPORT}

Nothing to declare

\section{REFERENCES}

Amorim HB, Francelino MR, Salamene S, Pedreira LOL, Assumpção-Filho LI, Capitano RC et al. Estimativa da área ocupada por reflorestamento no estado do Rio de Janeiro. Cerne 2012; 18(1): 27-32. http://dx.doi.org/10.1590/ S0104-77602012000100004.

Brubacher JP, Oliveira GG, Guasselli LA, Luerce TD. Avaliação de bases SRTM para extração de variáveis morfométricas e de drenagem. Revista Geociências 2012; 31(3): 381-393.

Calil Júnior C, Dias AA. Utilização da madeira em construções rurais. Revista Brasileira de Engenharia Agrícola e Ambiental 1997; 1(1): 71-77. http://dx.doi. org/10.1590/1807-1929/agriambi.v1n1p71-77. 
Empresa Brasileira de Pesquisa Agropecuária - EMBRAPA. Sistema brasileiro de classificação de solos. 3. ed. Brasília; 2013. 353 p.

Food and Agriculture Organization of the United Nations FAO. Soil Moisture Storage Capacity $(\mathrm{mm} / \mathrm{m})$ map [online]; 2007. [cited 2007 Feb 16]. Available from: http://www. fao.org/geonetwork/srv/en/main.home

Francelino MR, Rezende EMC, Silva LDB. Proposta de metodologia para zoneamento ambiental de plantio de eucalipto. Cerne 2012; 18(2): 275-283. http://dx.doi. org/10.1590/S0104-77602012000200012.

Golfari L. Manual de Reflorestamento do Estado do Rio de Janeiro. 1. ed. Rio de Janeiro: Secretaria de Planejamento e Coordenação Geral do Governo do Estado do Rio de Janeiro; 1980. 382 p.

Gonçalez JC, Breda LCS, Barros JFM, Macedo DM, Janin $\mathrm{G}$, Costa AF et al. Características tecnológicas das madeiras de Eucalyptus grandis W.Hill ex Maiden e Eucalyptus cloeziana F. Muell visando ao seu aproveitamento na indústria moveleira. Ciência Florestal 2006; 16(3): 329341. http://dx.doi.org/10.5902/198050981912.

Indústria Brasileira de Árvores - IBÁ. Indústria Brasileira de Árvores. Brasília: IBÁ; 2015. 80 p.

Lima IL, Garcia JN. Efeito da fertilização em propriedades mecânicas da madeira de Eucalyptus grandis. Ciência Florestal 2011; 21(3): 601-608. http://dx.doi.org/10.5902/198050983818.

Lyra GB, Santos MJ, Souza JL, Lyra GB, Santos MA. Espacialização da temperatura do ar anual para o estado de Alagoas com diferentes modelos digitais de elevação e resoluções espaciais. Ciência Florestal 2011;21(3): 275-287.

Lyra GB, Correia TP, Oliveira-Júnior JF, Zeri M. Evaluation of methods of spatial interpolation for monthly rainfall data over the state of Rio de Janeiro, Brazil. Theoretical and Applied Climatology 2017; 134: 1-11. http://dx.doi. org/10.1007/s00704-017-2322-3. [Continuous flow]

Mafra AL, Guedes SFF, Filho OK, Santos JCP, Almeida JA, Rosa, JD. Carbono orgânico e atributos químicos do solo em áreas florestais. Árvore 2008; 32(2):217-224.

Paula RP, Pereira MG, Santiago RR, Amorim HB. Propriedades edáficas e desenvolvimento de eucalipto em topossequência na flona Mário Xavier-RJ. Floresta e Ambiente 2012; 19(3): 344-351. http://dx.doi.org/10.4322/ floram.2012.040.

Pereira AR, Angelocci LR, Sentelhas PC. Agrometeorologia: fundamentos e aplicações práticas. Guaíba: Livraria e Editora Agropecuária; 2002. 478 p.
Rolim GS, Sentelhas PC, Barbieri V. Planilhas no ambiente excel para os cálculos de balanços hídricos: normal, sequencial, de cultura e de produtividade real e potencial. Revista Brasileira de Agrometeorologa 1998; 6(4): 133-137.

Santana RC, Barros NF, Neves JCL. Biomassa e conteúdo de nutrientes de procedências de Eucalyptus grandis e Eucalyptus saligna em alguns sítios florestais do estado de São Paulo. Scientia Forestalis 1999; 56(32): 155-169.

Silva PHM, Stape FJL, Brito JO, Moreira RM. Produção de óleo essencial e balanço nutricional Corymbia citriodora adubado com lodo de esgoto em diferentes espaçamentos. Revista Ceres 2009; 15(3): 346-354.

Schumacher MV, Poggiani F. Produção de biomassa e remoção de nutrientes em povoamentos de Eucalyptus camaldulensis Dehnh, Eucalyptus grandis Hill ex Maiden E Eucalyptus torelliana F. Muell, localizados em AnhembI - SP. Ciência Florestal 1993; 3(1): 21-32. http://dx.doi. org/10.5902/19805098283.

Sperandio HV. Zoneamento agroecológico para espécies de eucalipto no estado do Espírito Santo. Revista Caminhos da Geografia 2010; 11(34): 203-216.

Souza MJH, Ribeiro A, Leite LG, Leite FP, Minuzzi RB. Disponibilidade hídrica do solo e produtividade do eucalipto em três regiões da bacia do Rio Doce. Revista Árvore 2006; 30(3):399-410.

Tolfo ALT, Cesar PR, Bonine CAV, Bassa A, Valle, CF. Parâmetros genéticos para caracteres de crescimento, de produção e tecnológicos da madeira em clones de Eucalyptus spp. Scientia Forestalis 2005; 67(2): 101-110.

Thornthwaite CW, Mather JR. The water balance. Centerton: Drexel Institute of Technology, Laboratory of Climatology; 1955. 104 p. (Publications in Climatology; Vol. 8; no. 1).

Science for a Changing World - USGS. U.S. Geological Survey. Shuttle Radar Topography Mission, 1 Arc Second SRTM v 3.0 Topography [online] 2013. [cited 2013 May 20]. Available from: https://lta.cr.usgs.gov/SRTM1Arc.

Wilcken CF, Lima ACV, Dias TKR, Masson MV, Ferreira PJ Fo, Pogetto MHFAD. Guia Prático de Manejo de Plantações de Eucalipto. 21. ed. São Paulo: Fundação de Estudos e Pesquisas Agrícolas e Florestais; 2008. 25 p.

Vitti MAS, Brito JO. Avaliação do rendimento e do teor de citronelal do óleo essencial de procedência e raças locais de Eucalyptus citriodora. Scientia Forestalis 1999; 56(56): 145-154. 